\title{
The effective reduction of tourniquet application time after minor modification of the CLSI H03-A6 blood collection procedure
}

\author{
Gabriel Lima-Oliveira*1,2, Giuseppe Lippi ${ }^{3}$, Gian Luca Salvagno ${ }^{1}$, Martina Montagnana ${ }^{1}$, Geraldo Picheth ${ }^{2}$, Gian Cesare Guidi ${ }^{1,2}$ \\ 'Laboratory of Clinical Biochemistry, Department of Life and Reproduction Sciences, University of Verona, Italy \\ 2Post-Graduate Program of Pharmaceutical Sciences, Department of Medical Pathology Federal University of Parana, Curitiba, Parana, \\ Brazil \\ ${ }^{3}$ Pathology and Laboratory Medicine, Clinical Chemistry and Hematology Laboratory, Academic Hospital of Parma, Parma, Italy \\ *Corresponding author: dr.g.lima.oliveira@gmail.com
}

\begin{abstract}
Introduction: The phlebotomists' procedures are a still source of laboratory variability. The aim of this study was to verify the efficacy of minor modification in procedure for collection of diagnostic blood specimens by venipuncture from CLSI H03-A6 document is able to reduce the tourniquet application time.
\end{abstract}

Materials and methods: Thirty phlebotomists were invited to participate. Each phlebotomist was trained individually to perform the new venipuncture procedure that shortens the time of tourniquet release and removal. The phlebotomy training program was delivered over $8 \mathrm{~h}$. After training, all phlebotomists were monitored for 20 working days, to guarantee the adoption of the correct new procedures for collection of diagnostic blood specimens. After this time frame the phlebotomists were evaluated to verify whether the new procedure for blood collection derived from CLSI H03-A6 document was effective to improve the quality process by decrease in tourniquet application time. We compared the tourniquet application time and qualitative difference of phlebotomy procedures between laboratories before and after phlebotomy training.

Results: The overall mean $\pm S D$ tourniquet application time before and after this intervention were $118 \pm 1 \mathrm{~s}$ and $30 \pm 1 \mathrm{~s}$ respectively. Minor modifications in procedure for blood collection were able to reduce significantly the tourniquet application time $(-88 \mathrm{~s}, \mathrm{P}<0.001)$.

Conclusions: The minor modifications in procedure for collection of diagnostic blood specimens by venipuncture from CLSI H03-A6 document were able to reduce the tourniquet application time. Now the proposed new procedure for collection of diagnostic blood specimens by venipuncture could be considered usefulness and should be put into practice by all quality laboratory managers and/or phlebotomy coordinators to avoid preanalytical errors regard venous stasis and guarantee patient safety.

Key words: venous stasis; preanalytical phase; tourniquets; phlebotomy; practice guidelines

\section{Introduction}

The Clinical Laboratory Standard Institute (CLSI) mission is to develop best practices in clinical and laboratory testing and to promote their broad implementation by means of a consensus-driven process that balances the perspectives of industry, government, and the health care professions(1). The phlebotomists' procedures in private- and public laboratories in South America are far from being standardized or even harmonized (2). We previously showed that the wide distribution and implementation of the CLSI H03-A6 (3) document is able to improve the laboratory quality process, although the steps for collecting diagnostic blood specimens by venipuncture cannot be considered a gold standard yet, since inherent errors are still possible (i.e. variability as regards venous stasis) (4). From a practical standpoint, the tourniquet-induced venous stasis promotes the efflux of water, diffusible ions and low molecular weight substances from the vessel, thereby increasing the concen- 
tration of various blood analytes at the punctured site, thus influencing the correct interpretation of test results and increasing the likelihood of spurious variation (i.e., in vitro hemolysis) (5-7). The tourniquet application time and forearm clenching should be verified by every quality laboratory manager at work in the laboratory services, in order to both, eliminate this source of laboratory errors and safeguard the quality all through the total testing process. Based on our previous study, we had suggested changes on phlebotomy procedure steps from CLSI H03-A6 document as follows: i) to put on gloves, to cleanse the venipuncture site and to allow to dry before applying the tourniquet and selecting the venipuncture site and vein; ii) to release and remove the tourniquet immediately when the first tube starts to fill (4). The aim of this study was to verify the efficacy of minor modification in procedure for collection of diagnostic blood specimens by venipuncture from CLSI H03-A6 document (3) is able to reduce the tourniquet application time.

\section{Materials and methods}

\section{Phlebotomy training program}

The same thirty phlebotomists from São Paulo state (Brazil) previously appraised by us $(2,4)$, were invited to take part to this study. These professionals had 5 (4.8-5.6) years of experience in diagnostic blood specimens collection by venipuncture. The above professionals were operational at institutions ( 5 public- and 5 private-laboratories) where about 200 blood collections by venipuncture are performed per working day. Each phlebotomist was trained individually to perform the new venipuncture procedure as previously proposed by our group (4) with recent updates regarding the preanalytical phase $(8,9)$ (Table 1 , proposed new procedure). The phlebotomy training program was delivered over 8 hours, during which the importance of each step of the updated procedure was clearly explained (Table 1, importance of each step from proposed new procedure). One external/expert auditor from DICQ ${ }^{\circledR}$ trained all phlebotomists in one month (from September to October 2012). DICQ $^{\circledR}$ is a National System of Accreditation from
Brazilian Society of Clinical Analyses (10). This accreditation system is based on ISO 15189 document (11). After training, all phlebotomists were monitored by the laboratory quality manager (these professionals had followed the training too) for twenty working days, to guarantee the adoption of the correct procedures for the collection of diagnostic blood specimens, in agreement with the procedure proposed by our group (4). This period is generally considered sufficient by the quality laboratory's managers for including new procedures. Then each participating phlebotomist was re-evaluated during one normal working day. We decided to retrain and re-evaluate the thirty phlebotomists twice after the first assessment $(2,4)$, in order to minimize the inter-individual variability of performance since we were aware of the relevance of the workday routine of these professionals.

\section{Phlebotomy evaluation}

To assess the performance of the phlebotomists during the collection of diagnostic blood specimens the previously check list used was followed $(2,4)$. We aimed at re-evaluating: i) time of tourniquet application; ii) inappropriate requests to patients to clench their fist repeatedly; iii) excessively aggressive disinfection of the forearm by the phlebotomist, which can produce venous stasis; iv) drawing order of vacuum tubes during specimen collection; v) adequacy of mixing blood in primary vacuum tubes that contain anticoagulant or clot activating additives (as recommended by manufactures). So, this check list allowed the re-evaluation of whether this procedure for blood collection by venipuncture - a minor modification in CLSI H03A6 document (3) - was effective to improve the quality of the blood collection process by eliminating any possible source of errors, that we hypothesized was still current in this worldwide distributed and implemented document (CLSI H-03-A6).

To standardize the evaluation of tourniquet application time and to reduce bias, the performance of each phlebotomist was evaluated when blood was being collected from patients with the following characteristics: between the ages of 18 and 65 years, nonpregnant, nonobese (i.e., body mass in$\operatorname{dex}[\mathrm{BMI}]<30 \mathrm{~kg} / \mathrm{m}^{2}$ ), neither undergoing chemo- 
TABLE 1. Comparisons of CLSI H03-A6 and the new procedure for collection of diagnostic blood specimens by venipuncture.

\begin{tabular}{|c|c|c|c|c|}
\hline Step & $\begin{array}{l}\text { Current procedure recommended } \\
\text { by CLSI H03-A6 document }\end{array}$ & Step & Proposed new procedure & $\begin{array}{l}\text { Importance of each step from } \\
\text { proposed new procedure }\end{array}$ \\
\hline $\mathrm{i}$ & prepare accession order & $\mathrm{i}$ & prepare accession order & \\
\hline ii & $\begin{array}{l}\text { approach and indentify the patient; } \\
\text { sanitize hands }\end{array}$ & ii & $\begin{array}{l}\text { approach and indentify the patient; } \\
\text { sanitize hands }\end{array}$ & to guarantee patient identity assurance \\
\hline \multirow{2}{*}{ iii } & $\begin{array}{c}\text { verify the patient's fasting status or } \\
\text { diet restrictions, as appropriate, and } \\
\text { inquire }\end{array}$ & \multirow{2}{*}{ iii } & $\begin{array}{c}\text { verify the patient's fasting status or } \\
\text { diet restrictions, as appropriate, and } \\
\text { inquire }\end{array}$ & $\begin{array}{c}\text { fasting status is an important source of } \\
\text { variability }\end{array}$ \\
\hline & $\begin{array}{c}\text { if the patient has a latex sensitivity; } \\
\text { select appropriate gloves and } \\
\text { tourniquet }\end{array}$ & & $\begin{array}{c}\text { if the patient has a latex sensitivity; } \\
\text { select appropriate gloves and } \\
\text { tourniquet }\end{array}$ & $\begin{array}{c}\text { to prevent allergic reaction and/or } \\
\text { anaphylactic shock attributed to latex } \\
\text { allergy }\end{array}$ \\
\hline iv & $\begin{array}{c}\text { assemble necessary supplies and } \\
\text { select appropriate tubes according to } \\
\text { the requests }\end{array}$ & iv & $\begin{array}{l}\text { assemble necessary supplies and } \\
\text { select appropriate tubes according } \\
\text { to the requests }\end{array}$ & $\begin{array}{l}\text { to prevent errors in laboratory medicine } \\
\text { induced by supplies and addictives such } \\
\text { as anticoagulants and clot activators }\end{array}$ \\
\hline $\mathrm{v}$ & position the patient & $\mathrm{v}$ & position the patient & $\begin{array}{l}\text { to eliminate possible interferences of } \\
\text { blood distribution due to different posture }\end{array}$ \\
\hline vi & $\begin{array}{l}\text { apply the tourniquet and select the } \\
\text { venipuncture site and vein }\end{array}$ & vi & put on gloves & $\begin{array}{l}\text { preventing phlebotomists' exposure to } \\
\text { potentially infectious blood pathogens }\end{array}$ \\
\hline vii & put on gloves & vii & cleanse the venipuncture site & $\begin{array}{l}\text { cleaning prevents infection by skin } \\
\text { microorganisms }\end{array}$ \\
\hline viii & $\begin{array}{l}\text { cleanse the venipuncture site and } \\
\text { allow to dry }\end{array}$ & viii & $\begin{array}{l}\text { request the patient just close } \\
\text { his/her hand (never request the } \\
\text { patient to "pump") }\end{array}$ & $\begin{array}{l}\text { the clenching of the forearm before } \\
\text { venipuncture modifies the concentration } \\
\text { of several analytes (i.e. potassium) }\end{array}$ \\
\hline \multirow[t]{2}{*}{ ix } & $\begin{array}{l}\text { perform venipuncture; once blood } \\
\text { flow begins, request the patient to } \\
\text { open his/her hand }\end{array}$ & ix & $\begin{array}{l}\text { apply the tourniquet and select } \\
\text { the venipuncture site and vein }\end{array}$ & \multirow{3}{*}{ to prevent venous stasis and hemolysis } \\
\hline & & \multirow[t]{2}{*}{$\mathbf{x}$} & $\begin{array}{l}\text { perform venipuncture; once } \\
\text { blood flow begins, request the } \\
\text { patient to open his/her hand }\end{array}$ & \\
\hline$x$ & $\begin{array}{l}\text { fill tubes using the correct order of } \\
\text { draw }\end{array}$ & & $\begin{array}{l}\text { also release and remove the } \\
\text { tourniquet }\end{array}$ & \\
\hline$x i$ & release and remove the tourniquet & $\mathbf{x i}$ & $\begin{array}{l}\text { fill tubes using the correct order } \\
\text { of draw }\end{array}$ & $\begin{array}{c}\text { to prevent errors by cross contamination } \\
\text { between additives }\end{array}$ \\
\hline xii & $\begin{array}{l}\text { place the gauze pad over the } \\
\text { puncture site }\end{array}$ & xii & $\begin{array}{l}\text { place the gauze pad over the } \\
\text { puncture site }\end{array}$ & \multirow{2}{*}{$\begin{array}{l}\text { safe feature for preventing phlebotomists } \\
\text { exposure to potentially infections by } \\
\text { bloodborne pathogens }\end{array}$} \\
\hline xiii & $\begin{array}{l}\text { remove the needle, activate any safety } \\
\text { feature, and dispose of the device }\end{array}$ & xiii & $\begin{array}{l}\text { remove the needle, activate any safety } \\
\text { feature, and dispose of the device }\end{array}$ & \\
\hline xiv & $\begin{array}{c}\text { apply pressure to the site, making } \\
\text { sure bleeding has stopped, and then } \\
\text { bandage the arm }\end{array}$ & xiv & $\begin{array}{l}\text { apply pressure to the site, making } \\
\text { sure bleeding has stopped, and then } \\
\text { bandage the arm }\end{array}$ & $\begin{array}{c}\text { applying pressure to the site is an efficient } \\
\text { prevention of bruise }\end{array}$ \\
\hline$x v$ & $\begin{array}{c}\text { label the tubes and record the time of } \\
\text { collection; some facilities also specify } \\
\text { phlebotomist }\end{array}$ & \multirow[t]{2}{*}{$\mathrm{xv}$} & $\begin{array}{c}\text { label the tubes and record the time } \\
\text { of collection; some facilities also } \\
\text { specify phlebotomist }\end{array}$ & \multirow[t]{2}{*}{$\begin{array}{l}\text { to reduce missing identification and } \\
\text { guarantee the traceability of the process }\end{array}$} \\
\hline & identification on the tubes & & identification on the tubes & \\
\hline $\mathrm{xvi}$ & $\begin{array}{l}\text { observe special handling } \\
\text { requirements (if any required) }\end{array}$ & $\mathrm{xvi}$ & $\begin{array}{l}\text { observe special handling } \\
\text { requirements (if any required) }\end{array}$ & \multirow{2}{*}{$\begin{array}{l}\text { - to guarantee diagnostic blood specimens } \\
\text { stability }\end{array}$} \\
\hline xvii & $\begin{array}{c}\text { send properly labeled blood } \\
\text { collection tubes to the appropriate } \\
\text { laboratories }\end{array}$ & xvii & $\begin{array}{l}\text { send properly labeled blood } \\
\text { collection tubes to the appropriate } \\
\text { laboratories }\end{array}$ & \\
\hline
\end{tabular}

Steps in bold text represent changes in current procedure recommended by CLSI H03-A6 document (3) suggested by Lima-Oliveira et al. (4). 
therapy nor catheterization, and not afflicted with any apparent vascular disease. All these conditions were carefully excluded because they might be associated with difficulties during the collection of diagnostic blood specimens, which thereby might introduce bias into the evaluation. The performance of each phlebotomist was monitored in 5 different phlebotomies; the time of tourniquet application was measured with a calibrated chronometer. The time interval between tourniquet application and removal was recorded in seconds. This procedure is the same procedure published and used by us before to evaluate phlebotomists' performance $(2,4)$.

\section{Statistical analysis}

The tourniquet application time showed normal distribution (Kolmogorov-Smirnov test; $\mathrm{P}>0.05$ ) and date were expressed as mean \pm standard deviation (SD). Differences were tested by paired Student t-test. Fisher exact test (two-tailed) was used to compare the qualitative differences of the phlebotomy procedures among laboratories before and after phlebotomy training. McNemar Chisquare test for dependent samples was used to compare before-after laboratory training. The values with $P<0.05$ were considered statistically significant. Statistical analyses were performed with Statistica for Windows, version 8.0 (StatSoft Inc., Tulsa, OK, USA).

\section{Results}

The results are shown in table 2 and table 3 . The new phlebotomy instruction was able to eliminate several non-conformities, especially those related to prolonged tourniquet application time (Table 3); the overall mean $\pm S D$ was $30 \pm 1 \mathrm{~s}$. Private laboratories applied the tourniquet for statistically significant shorter times than public laboratories ( $28 \pm 1$ s vs. $32 \pm 1$ s; $P=0.002)$. None of the phlebotomist inappropriately requested that the patient clench their fist repeatedly (i.e., more than twice).

\section{Discussion}

Our results show that the procedure previously proposed (4) reduces drastically the tourniquet application time. The overall mean \pm SD before and

TABLE 2. Improvement of phlebotomy error rates pre- and post- training of H03-A6 and proposed new procedure.

\begin{tabular}{|c|c|c|c|c|c|c|c|c|c|c|c|c|}
\hline \multirow[b]{2}{*}{ Error description } & \multicolumn{4}{|c|}{ Laboratories before training \# } & \multicolumn{4}{|c|}{$\begin{array}{l}\text { Laboratories after training } \\
\text { with CLSI H03-A6 document \#\# }\end{array}$} & \multicolumn{4}{|c|}{$\begin{array}{l}\text { Laboratories after training } \\
\text { with new procedure }\end{array}$} \\
\hline & $\begin{array}{c}\text { All } \\
(\mathrm{N}=30)\end{array}$ & $\begin{array}{c}\text { Public } \\
\text { Lab } \\
(\mathrm{N}=15)\end{array}$ & $\begin{array}{c}\text { Private } \\
\text { Lab } \\
(\mathrm{N}=15)\end{array}$ & $\mathbf{P}$ & $\begin{array}{c}\text { All } \\
(N=30)\end{array}$ & $\begin{array}{c}\text { Public } \\
\text { Lab } \\
(\mathrm{N}=15)\end{array}$ & $\begin{array}{c}\text { Private } \\
\text { Lab } \\
(\mathrm{N}=15)\end{array}$ & $\mathbf{P}$ & $\begin{array}{c}\text { All } \\
(N=30)\end{array}$ & $\begin{array}{c}\text { Public } \\
\text { Lab } \\
(\mathrm{N}=15)\end{array}$ & $\begin{array}{l}\text { Private } \\
\text { Lab } \\
(\mathrm{N}=15)\end{array}$ & $\mathbf{P}$ \\
\hline $\begin{array}{l}\text { Inappropriate request to } \\
\text { the patient to clench the } \\
\text { fist repeatedly }\end{array}$ & $25 / 30$ & $14 / 15$ & $11 / 15$ & 0.329 & $29 / 30^{*}$ & $15 / 15$ & $14 / 15$ & 1.000 & $0 / 30 * * *$ & $0 / 15$ & $0 / 15$ & --- \\
\hline $\begin{array}{l}\text { Inadequate friction } \\
\text { procedure during } \\
\text { the cleaning of the } \\
\text { venipuncture site }\end{array}$ & $27 / 30$ & $13 / 15$ & $14 / 15$ & 1.000 & $0 / 30^{* *}$ & $0 / 15$ & $0 / 15$ & --- & $0 / 30$ & $0 / 15$ & $0 / 15$ & ---- \\
\hline $\begin{array}{l}\text { Incorrect sequence of } \\
\text { vacuum tubes }\end{array}$ & $26 / 30$ & $13 / 15$ & $12 / 15$ & 1.000 & $0 / 30 * *$ & $0 / 15$ & $0 / 15$ & --- & $0 / 30$ & $0 / 15$ & $0 / 15$ & ---- \\
\hline $\begin{array}{l}\text { Incorrect mixing of } \\
\text { vacuum tubes }\end{array}$ & $25 / 30$ & $15 / 15$ & $10 / 15$ & 0.042 & $0 / 30^{* *}$ & $0 / 15$ & $0 / 15$ & --- & $0 / 30$ & $0 / 15$ & $0 / 15$ & ---- \\
\hline \multicolumn{13}{|c|}{$\begin{array}{l}\text { Comparison of error rates between public and private laboratories before training (McNemar Chi-square test, }{ }^{*} \mathrm{P}=0.113 \text { and }{ }^{* *} \mathrm{P}< \\
0.001) \text {, and after training to the proposed new procedure (Fisher exact test two-tailed test }{ }^{* * *} \mathrm{P}<0.001{ }^{* * * *} \mathrm{P}=0.237 \text { ). } \\
\text {---, not calculated; } \\
\text { \# data previously published (2); } \\
\text { \#\# data previously published (4). }\end{array}$} \\
\hline
\end{tabular}


after this intervention were $118 \pm 1 \mathrm{~s}$ and $30 \pm 1 \mathrm{~s}$ respectively (Table 3 ). Minor modifications in procedure for blood collection were able to reduce significantly the tourniquet application time (-88 s,
$P<0.001)$. This significant reduction of the application time is able to eliminate the venous stasis impact, that is an important source of unpredictable laboratory variability $(5-8,12-14)$. Private laborato-

TABLE 3. Evaluation of tourniquet application time after phlebotomy training program (CLSI H03-A6 document vs. New procedure).

\begin{tabular}{|c|c|c|c|c|c|}
\hline \multirow[b]{2}{*}{ Laboratories } & \multirow[b]{2}{*}{ Phlebotomists } & \multicolumn{3}{|c|}{ Tourniquete time (s) } & \multirow[b]{2}{*}{ P-value } \\
\hline & & $\begin{array}{c}\text { Procedure from } \\
\text { CLSI H03-A6 \# } \\
\text { (mean } \pm \text { SD) }\end{array}$ & $\begin{array}{c}\text { New Procedure } \\
\text { (mean } \pm \text { SD) }\end{array}$ & Difference & \\
\hline \multirow{3}{*}{1 Public } & 1 & $156 \pm 3$ & $31 \pm 2$ & -125 & $<0.001$ \\
\hline & 2 & $154 \pm 1$ & $32 \pm 2$ & -122 & $<0.001$ \\
\hline & 3 & $154 \pm 2$ & $31 \pm 1$ & -123 & $<0.001$ \\
\hline \multirow{3}{*}{2 Public } & 4 & $144 \pm 1$ & $32 \pm 1$ & -112 & $<0.001$ \\
\hline & 5 & $140 \pm 1$ & $33 \pm 2$ & -107 & $<0.001$ \\
\hline & 6 & $141 \pm 1$ & $32 \pm 1$ & -109 & $<0.001$ \\
\hline \multirow{3}{*}{3 Public } & 7 & $153 \pm 2$ & $31 \pm 1$ & -122 & $<0.001$ \\
\hline & 8 & $150 \pm 1$ & $32 \pm 1$ & -118 & $<0.001$ \\
\hline & 9 & $149 \pm 1$ & $31 \pm 1$ & -118 & $<0.001$ \\
\hline \multirow{3}{*}{4 Public } & 10 & $145 \pm 1$ & $33 \pm 2$ & -112 & $<0.001$ \\
\hline & 11 & $144 \pm 2$ & $31 \pm 1$ & -113 & $<0.001$ \\
\hline & 12 & $146 \pm 1$ & $31 \pm 2$ & -115 & $<0.001$ \\
\hline \multirow{3}{*}{5 Public } & 13 & $147 \pm 1$ & $32 \pm 1$ & -115 & $<0.001$ \\
\hline & 14 & $146 \pm 2$ & $32 \pm 3$ & -114 & $<0.001$ \\
\hline & 15 & $147 \pm 1$ & $32 \pm 1$ & -115 & $<0.001$ \\
\hline \multirow{3}{*}{1 Private } & 16 & $97 \pm 1$ & $30 \pm 1$ & -67 & $<0.001$ \\
\hline & 17 & $92 \pm 1$ & $29 \pm 1$ & -63 & $<0.001$ \\
\hline & 18 & $90 \pm 1$ & $30 \pm 1$ & -60 & $<0.001$ \\
\hline \multirow{3}{*}{2 Private } & 19 & $87 \pm 2$ & $25 \pm 1$ & -62 & $<0.001$ \\
\hline & 20 & $84 \pm 1$ & $26 \pm 1$ & -58 & $<0.001$ \\
\hline & 21 & $85 \pm 1$ & $26 \pm 1$ & -59 & $<0.001$ \\
\hline \multirow{3}{*}{3 Private } & 22 & $83 \pm 2$ & $28 \pm 2$ & -55 & $<0.001$ \\
\hline & 23 & $81 \pm 1$ & $27 \pm 2$ & -54 & $<0.001$ \\
\hline & 24 & $80 \pm 1$ & $29 \pm 2$ & -51 & $<0.001$ \\
\hline \multirow{3}{*}{4 Private } & 25 & $83 \pm 2$ & $26 \pm 1$ & -57 & $<0.001$ \\
\hline & 26 & $85 \pm 3$ & $26 \pm 1$ & -59 & $<0.001$ \\
\hline & 27 & $87 \pm 1$ & $27 \pm 1$ & -60 & $<0.001$ \\
\hline \multirow{3}{*}{5 Private } & 28 & $95 \pm 1$ & $28 \pm 1$ & -67 & $<0.001$ \\
\hline & 29 & $90 \pm 2$ & $27 \pm 1$ & -63 & $<0.001$ \\
\hline & 30 & $93 \pm 1$ & $29 \pm 1$ & -64 & $<0.001$ \\
\hline
\end{tabular}

Differences between CLSI H03-A6 and New procedure are shown in seconds and were tested by paired Student t-test (P-value). \# date of tourniquet time from training with CLSI H03-A6 document were previously published (4). 
ries exhibit a significantly lower time of tourniquet application than public laboratories after the training period (i.e., $31.7 \pm 0.7$ vs. $27.5 \pm 1.6 \mathrm{~s} ; \mathrm{P}<0.001$ ). A reliable explanation for this is that private laboratories have more ergonomic furniture in blood collection rooms (4). Recently Bölenius et al. (15) used the hemolysis index (HI) to assess the efficiency of a large-scale $2 \mathrm{~h}$ educational intervention, concluding that the training had only minor effects on blood collection practices. This largescale $2 \mathrm{~h}$ education intervention was supported by laboratory instructors from the Country Council of northern Sweden focusing on rehearsal and implementation of the national and local venous blood specimen collection guidelines that is similar to international standards (CLSI H03-A6 document). In our opinion, this kind of training program should instead be strongly recommended and performed worldwide. Moreover, previous investigations had shown that educational program and technological interventions for phlebotomists are relevant and promote decrease of sample errors consequently resulting in quality improvement (16-19). Maybe Bölenius et al. found only minor effects because the rules of the CLSI H03-A6 document increase the tourniquet application time and the Sweden guidelines recommend to reverse vacuum tubes 5-10 times using an automatic mixer by inversion without rest after filling of the tubes. Paternmark and Landberg convincingly demonstrated that: (a) mixing blood samples immediately after collection may not be mandatory for all types of tubes; and (b) instant mixing by automatic mixer may produce spurious hemolysis and thereby introduce a bias for those parameters that are most susceptible to RBC injury (9). Therefore, the quality indicator $\mathrm{HI}$ chosen by Bölenius et al. was fully influenced by the phlebotomy guidelines used. Continuous monitoring and management of preanalytical errors (i.e., by quality indicators) are crucial for improving the quality of laboratory performance, and are also necessary for all clinical laboratories accredited by International Organization for Standardization (ISO) document 15189 $(11,20-22)$. Some recent updates regarding the preanalytical phase should be considered when performing a phlebotomy training program, such as: i) supply changes among different manufacturers of syringes for blood gas analyses, which can represent new sources of laboratory variability; and likewise for not in-laboratory validated vacuum tubes by the quality laboratory managers (as recommended by ISO 15189 document) (23-27); ii) transport boxes which do not guarantee the maintenance of the temperature during blood specimens transportation (28); iii) consolidated paradigms ranging from filling of vacuum tubes to mixing procedures which appear unsupported by accurate experimental verification; e.g., all blood specimens collected in vacuum tube systems by venipuncture apparently do not need to be mixed (9). Moreover apparently incorrect vigorous mixing of the primary blood vacuum tubes does not promote laboratory variability (29); more so, no clinical impact has been observed in routine and specialized coagulation laboratory testing when the vacuum tubes are incompletely filled (when filled to more than $90 \%$ but less than 100\%) (8).

In conclusion, for a long time the preanalytical phase has been known as the "dark side of the moon" (30-35). The minor modifications in procedure for collection of diagnostic blood specimens by venipuncture from CLSI H03-A6 document were able to reduce the tourniquet application time. Now the proposed new procedure for collection of diagnostic blood specimens by venipuncture should be strongly suggested for use by all quality laboratory managers and/or phlebotomy coordinators in their services in order to avoid preanalytical errors regard venous stasis and guarantee patient safety.

\section{Potential conflict of interest}

None declared. 


\section{References}

1. Clinical Laboratory Standards Institute. Mission of Clinical and Laboratory Standards Institute. 2012 Available from: http://www.clsi.org/Content/NavigationMenu/AboutCLSI/ VisionMissionandValues/Vision_Mission_Value.htm. Accessed 4th March 2013.

2. Lima-Oliveira G, Guidi GC, Salvagno GL, Montagnana M, Rego FGM, Lippi G, et al. Is phlebotomy part of the dark side in the clinical laboratory struggle for quality? Lab Med 2012;43:17-21. http://dx.doi.org/10.1309/LMZ7YARD6ZSDIID.

3. Clinical Laboratory Standards Institute. Procedures for the collection of diagnostic blood specimens by venipuncture. CLSI H3-A6 document. 6th ed. Wayne, PA: Clinical Laboratory Standards Institute; 2007.

4. Lima-Oliveira G, Lippi G, Salvagno GL, Montagnana M, Picheth $G$, Guidi GC. Impact of the phlebotomy training based on CLSI/NCCLS H03-A6 - procedures for the collection of diagnostic blood specimens by venipuncture. Biochem Med 2012;22:342-51. http://dx.doi.org/10.11613/BM.2012.036.

5. Lima-Oliveira G, Salvagno GL, Lippi G, Montagnana $M$, Scartezini $M$, Picheth $G$, et al. Elimination of the venous stasis error for routine coagulation testing by transillumination. Clin Chim Acta 2011;412:1482-4. http://dx.doi. org/10.1016/j.cca.2011.04.008.

6. Lima-Oliveira G, Lippi G, Salvagno GL, Montagnana M, Mangueira C, Sumita N, et al. New ways to deal with known preanalytical issues: use of transilluminator instead of tourniquet for easing vein access and eliminating stasis on clinical biochemistry. Biochem Med 2011;21:152-9. http:// dx.doi.org/10.11613/BM.2011.024.

7. Lima-Oliveira G, Lippi G, Salvagno GL, Montagnana $M$, Scartezini M, Guidi GC, et al. Transillumination: a new tool to eliminate the impact of venous stasis during the procedure for the collection of diagnostic blood specimens for routine haematological testing. Int J Lab Hematol 2011;33:457-62.

8. Lippi G, Salvagno GL, Montagnana M, Lima-Oliveira G, Guidi GC, Favaloro EJ. Quality Standards for Sample Collection in Coagulation Testing. Semin Thromb Hemost 2012;38:565-75. http://dx.doi.org/10.1055/s-00321315961.

9. Parenmark A, Landberg E. To mix or not to mix venous blood samples collected in vacuum tubes? Clin Chem Lab Med 2011;49:2061-3. http://dx.doi.org/10.1515/CCLM.2011.705.

10. National System of Accreditation-Brazilian Society of Clinical Analyses. Manual for accreditation of quality management system for clinical laboratories. 5th ed. Available from: http://www.dicq.org.br/pdfs/manual_dicq_2011. pdf: Brazilian Society of Clinical Analyses; 2011. Accessed 1th March 2013.

11. International Organization for Standardization. Medical laboratories - Particular requirements for quality and competence ISO document 15189. 2nd ed. Geneva, Switzerland: International Organization for Standardization; 2007.
12. Lippi G, Salvagno GL, Montagnana M, Brocco G, Guidi GC. Influence of short-term venous stasis on clinical chemistry testing. Clin Chem Lab Med 2005;43:869-75. http://dx.doi. org/10.1515/CCLM.2005.146.

13. Lippi G, Salvagno GL, Montagnana M, Franchini M, Guidi GC. Venous stasis and routine hematologic testing. Clin Lab Haematol 2006;28:332-7. http://dx.doi.org/10.1111/ j.1365-2257.2006.00818.x.

14. Lippi G, Salvagno GL, Montagnana M, Guidi GC. Shortterm venous stasis influences routine coagulation testing. Blood Coagul Fibrinolysis 2005;16:453-8. http://dx.doi. org/10.1097/01.mbc.0000178828.59866.03.

15. Bölenius K, Söderberg J, Hultdin J, Lindkvist M, Brulin C, Grankvist K. Minor improvement of venous blood specimen collection practices in primary health care after a large-scale educational intervention. Clin Chem Lab Med 2013;51:303-10. http://dx.doi.org/10.1515/cclm-2012-0159.

16. Lillo $R$, Salinas $M$, Lopez-Garrigos $M$, Naranjo-Santana $Y$, Gutierrez M, Marin MD, et al. Reducing preanalytical laboratory sample errors through educational and technological interventions. Clin Lab 2012;58:911-7.

17. Lowe G, Stike R, Pollack M, Bosley J, O'Brien P, Hake A, et al. Nursing blood specimen collection techniques and hemolysis rates in an emergency department: analysis of venipuncture versus intravenous catheter collection techniqu es. J Emerg Nurs 2008;34:26-32. http://dx.doi.org/10.1016/j. jen.2007.02.006.

18. Bailey IR, Thurlow VR. Is suboptimal phlebotomy technique impacting on potassium results for primary care? Ann Clin Biochem 2008;45:266-9. http://dx.doi.org/10.1258/ acb.2007.007123.

19. Straszewski SM, Sanchez L, McGillicuddy D, Boyd K, Dufresne J, Joyce $N$, et al. Use of separate venipunctures for IV access and laboratory studies decreases hemolysis rates. Intern Emerg Med 2011;6:357-9. http://dx.doi.org/10.1007/ s11739-011-0568-9.

20. Simundic AM, Nikolac N, Vukasovic I, Vrkic N. The prevalence of preanalytical errors in a Croatian ISO 15189 accredited laboratory. Clin Chem Lab Med 2010;48:1009-14. http:// dx.doi.org/10.1515/cclm.2010.221.

21. Simundic $A M$, Bilic-Zulle L, Nikolac $N$, Supak-Smolcic $V$, Honovic L, Avram S, et al. The quality of the extra-analytical phase of laboratory practice in some developing European countries and Mexico - a multicentric study. Clin Chem Lab Med 2011;49:215-28. http://dx.doi.org/10.1515/ cclm.2011.034.

22. Guzel O, Guner El. ISO 15189 Accreditation: Requirements for quality and competence of medical laboratories, experience of a laboratory I. Clin Biochem 2009;42:274-8. http:// dx.doi.org/10.1016/j.clinbiochem.2008.09.011.

23. Lima-Oliveira G, Lippi G, Salvagno GL, Montagnana M, Picheth $G$, Guidi GC. Different manufacturers of syringes: $A$ new source of variability in blood gas, acid-base balance and related laboratory test? Clin Biochem 2012;45:683-7. http://dx.doi.org/10.1016/j.clinbiochem.2012.03.007. 
24. Lima-Oliveira G, Lippi G, Salvagno GL, Montagnana M, Picheth $G$, Guidi GC. Pre analytical management: serum vaccum tubes validation for routine clinical chemistry. Biochem Med 2012;22:180-6. http://dx.doi.org/10.11613/ BM.2012.021.

25. Lima-Oliveira G, Lippi G, Salvagno GL, Montagnana M, Picheth $G$, Guidi GC. Sodium citrate vacuum tubes validation: preventing preanalytical variability in routine coagulation testing. Blood Coagul Fibrinolysis 2013;24:252-5. http:// dx.doi.org/10.1097/MBC.0b013e32835b72ea.

26. Lima-Oliveira G, Lippi G, Salvagno GL, Montagnana $M$, Poli $G$, Solero GP, et al. K3EDTA vacuum tubes validation for routine hematological testing. ISRN Hematology 2012;2012:875357. http://dx.doi.org/10.5402/ 2012/875357.

27. Lima-Oliveira G, Salvagno GL, Lippi G, Brocco G, Voi $M$, Montagnana $M$, et al. Quality management of preanalytical phase: impact of lithium heparin vacuum tubes changes on clinical chemistry. Accred Qual Assur 2013;18:42934. http://dx.doi.org/10.1007/s00769-013-0995-6.

28. Lippi G, Lima-Oliveira G, Nazer SC, Moreira ML, Souza RF, Salvagno GL, et al. Suitability of a transport box for blood sample shipment over a long period. Clin Biochem 2011;44:1028-9. http://dx.doi.org/10.1016/j.clinbiochem. 2011.05 .028 .
29. Lima-Oliveira G, Lippi G, Salvagno GL, Montagnana $M$, Gelati $M$, Volanski $W$, et al. Effects of vigoros mixing of blood vacuum tubes on laboratory test results. Clin Biochem 2013;46:250-4. http://dx.doi.org/10.1016/j. clinbiochem.2012.10.033.

30. Lippi G, Guidi GC, Mattiuzzi C, Plebani M. Preanalytical variability: the dark side of the moon in laboratory testing. Clin Chem Lab Med 2006;44:358-65. http://dx.doi.org/10.1515/ CCLM.2006.073.

31. Bowen RA, Hortin GL, Csako G, Otanez OH, Remaley AT. Impact of blood collection devices on clinical chemistry assays. Clin Biochem 2010;43:4-25. http://dx.doi.org/10.1016/j. clinbiochem.2009.10.001.

32. Gren B. Incorrect guidelines for venipuncture affect the analytical results. Scand J Clin Lab Invest 2009;69:815-6. http://dx.doi.org/10.3109/00365510903307970.

33. Carraro P, Plebani M. Errors in a stat laboratory: types and frequencies 10 years later. Clin Chem 2007;53:1338-42. http://dx.doi.org/10.1373/clinchem.2007.088344.

34. Lippi G, Guidi GC. Risk management in the preanalytical phase of laboratory testing. Clin Chem Lab Med 2007;45:720-7. http://dx.doi.org/10.1515/CCLM.2007.167.

35. Plebani $M$, Carraro P. Mistakes in a stat laboratory: types and frequency. Clin Chem 1997;43:1348-51. 